\title{
The SphKs/S1P/S1PR1 axis in immunity and cancer: more ore to be mined
}

\author{
Lei Jin ${ }^{1}$, Wei-Ren Liu', Meng-Xin Tian', Jia Fan ${ }^{1,2}$ and Ying-Hong Shi ${ }^{*}$
}

\begin{abstract}
Over the past two decades, huge amounts of research were launched to understand the functions of sphingosine. Many pathways were uncovered that convey the relative functions of biomacromolecules. In this review, we discuss the recent advances of the role of the SphKs/S1P/S1PR1 axis in immunity and cancer. Finally, we investigate the therapeutic potential of new drugs that target S1P signaling in cancer therapy.
\end{abstract}

Keywords: SphKs/S1P/S1PR1, Immunity, Cancer

\section{Background}

Sphingosine was first described by J. L. in the 1880s, and its structure was characterized as $2 \mathrm{~S}, 3 \mathrm{R}, 4 \mathrm{E}$-2-aminooctadec-4-ene-1,3-diol [1]. In the last two decades, research has illustrated the significant functions of sphingosine in physiology, pathology, and the chemical or structural biology of metabolism.

Sphingosine kinases (SphKs) are comprised of two forms, SphK1 and SphK2, which are upstream of S1P. They catalyze the phosphorylation of sphingosine to S1P, regulating the amount of S1P [2]. The functions of these two S1P metabolic enzymes are critical. Double-knockout animals were embryonic lethal, due to the incomplete maturation of the vascular system and brain, although mice deficient in either SphK1 or SphK2 had no obvious abnormalities [3]. The differences in SphKs existed at an early stage. On a macro level, SphKs are activated by numerous stimuli, including chemokines, intercellular adhesion molecules, and pro-inflammatory cytokines $[4,5]$. On a molecular level, SphK1-S225A, Calcium and Integrinbinding protein 1, Elongation Factor 1A (eEF1a), and hypoxia regulate the specific microenvironment of SphKs [6-8]. Sphingosine, SphKs, and S1P regulation was more complex in cell nuclei. Hait N. C. et al. reported that the S1P produced by SphK2 inhibited histone deacetylases (HDACs), which modulated the dynamic balance of histone acetylation and influenced the epigenetic regulation of

\footnotetext{
* Correspondence: shi.yinghong@zs-hospital.sh.cn

${ }^{1}$ Department of Liver Surgery, Liver Cancer Institute, Zhongshan Hospital, Fudan University; Key Laboratory of Carcinogenesis and Cancer Invasion of Ministry of Education, 180 FengLin Road, Shanghai 200032, China Full list of author information is available at the end of the article
}

specific target genes [9]. SphK2 inhibited cell growth and promoted apoptosis [2]. In addition, the binding of S1P was also required for the E3 ubiquitin ligase activity of TRAF2, an essential mediator of the nuclear factor- $k B$ (NF-kB) pathway initiated by the major inflammatory signaling molecule TNF- $\alpha$ [10-12]. S1P may promote cancer progression via HDAC1/2 and NF- $\mathrm{kB}$ intracellular targets $[4,9,10]$. SphK1 was reported to contribute to S1P synthesis by a combination of epigenetic, transcriptional, and posttranslational mechanisms [13]. Therefore, SphK1 may have a more positive effect on S1P than SphK2.

It was unclear whether a SphKs/S1P regulatory loop existed in cells. Pappu R found that in an "S1P-less" mouse model, SphK1 and SphK2 were also disrupted in blood stem cells, vasculature, liver, and additional tissues [14].

Sphingosine-1-phosphate (S1P) is a common, complex molecule biosynthesized in our bodies. Its complicated structure forms via several steps. Sphingolipid biosynthesis is initiated in the endoplasmic reticulum (ER) [15]. Sphingolipid and S1P maintain a dynamic balance via a series of biosynthetic or recycling/degradation pathways and are phosphorylated or dephosphorylated by specific and nonspecific lipid phosphatases [2].

In the ER, sphingosine-1-phosphate phosphatase 1 (SPP1) and sphingosine-1-phosphate phosphatase 2 (SPP2), two sphingoid base-specific phosphatases, regulate S1P levels [16]. SPP1 gains access to extracellular S1P via its import into the cell by an ATP-binding cassette $(\mathrm{ABC})$ transporter [17], similar to agonists which activate SphK1 by inducing its recruitment to the 
plasma membrane and producing S1P by "inside-out signaling" [18-21]. SPP2 influences branching morphogenesis during kidney development by influencing S1P levels in the metanephric mesenchyme [16].

As discussed above, SphKs hold important guide roles in this process. Degradation is also important to balance the amount of S1P. S1P is degraded by the intracellular protein S1P lyase. In this process, the sphingoid base is cleaved at position $\mathrm{C} 2,3$, yielding hexadecenal and ethanolamine phosphate [22]. S1P lyase was upregulated in response to ischemia, radiation, and chemical injury in other tissues [2] and was also regulated by PDGF signaling [23]. Similar to SphKs, S1P lyase also maintained a dynamic balance.

Interestingly, the S1P lyase level in the blood was much lower than that in tissues, leading to higher S1P levels in the blood and lower amounts in tissues. Erythrocytes and platelets lack S1P lyase or S1P phosphatase activity when they mature [14]. Hagen found that loss of S1P lyase (SPL) resulted in high, cytotoxic S1P levels in the neurons and vital organs [24]. This observation is contradictory to early studies in SPL null mice, which form pathological lesions in the lung, heart, urinary tract, and bone due to lack of S1P $[9,25]$. Upstream of S1P, many molecules need further study.

The S1P receptors are regulated through distinct mechanisms. Transcriptional regulation of S1PR1 is controlled by Krüppel-like factor 2 (KLF-2), and S1PR1 is exquisitely sensitive because of ligand-induced internalization [26]. Although the S1P receptors emit signals in the presence of S1P, they also signal without S1P due to the downstream signaling of G protein partners [27]. Recent studies exposed an interesting phenomenon, in which Dynamin-2 was essential for S1PR1 internalization and promoted egress from both the thymus and lymph nodes wherever high S1P concentrations existed [28].

S1PR1 correlated with S1PR1-JAK/STAT3 signaling in Treg cells [29]. Its specific role in immunity is discussed below.

\section{The role of the SphK/S1P/S1PR1 axis in immune regulation}

SphK1-generated S1P participates in many physiological and pathological processes. S1P binds to five-cell surface receptors, called S1PR1-5. S1PRs performed important functions. S1PR1 is particularly distinctive. It plays an important role in the mature vascular system, pathological angiogenesis, immune cell egress from tissue compartments, hematopoietic, vascular and stem cell survival, cytokine production, and so on [30-34]. An interesting study noted that SphKs-S1P exist in the mitochondria, where the balance of their amounts influences respiration [12].

Hematopoietic stem and progenitor cells (HSPCs/ HSC/HPC) express S1P receptors. Following different
S1P gradients, HSPCs emigrated from peripheral tissues to the lymphatic system [35, 36]. Coincidentally, the egress of $\mathrm{B}$ cell progenitors from the bone marrow (BM) depended on S1P/S1PR1 interactions [37]. Furthermore, S1PR1 was required for the steady-state trafficking of HSPCs. Suppression of S1PR1 expression by genetic or pharmacologic methods significantly impaired the mobilization of HSPCs into the blood. CXCR4 blockade or the S1PR1 agonist SEW2871 enhanced AMD3100mediated HSC mobilization [38]. In addition, the release of S1P from mast cells and erythrocytes in the peripheral circulation was dependent on ATP-binding cassette $(\mathrm{ABC})$ transporters. This phenomenon was similar in either physiological or pathological situations [21, 39]. Interestingly, Henrik Fyrst raised the critical view why, with the help of S1P receptors for immune cell egress, some specific functions of non-lymphoid immune cells existed, perhaps by an as yet unknown feedback mechanism from other cells that influence S1P-S1PR (especially S1PR1) sensitivity [2].

Apart from the function for HSPCs, S1P and its receptors influence many organs through systemic and localized chemotactic gradients [40, 41]. Studies investigated the mechanisms underlying these phenomena. In an inflamed lymphoid organ, type 1 interferons (IFNs) increased the lymphocyte expression of the activation antigen CD69, which bound S1PR1 and induced its internalization and degradation through the loss of CCR7 in newly generated effector $\mathrm{T}$ cells, where S1PR1 was upregulated $[42,43]$. In the spleen, the S1P-S1PR1 axis changed cyclically, which allowed B cell migration in a CXC-chemokine receptor 5 (CXCR5-dependent manner toward CXC-chemokine ligand 13 (CXCL13), which is produced by follicular DCs [44]. Faroudi, M explained that S1PR1 played a crucial role in the reverse transmigration of lymphocytes by regulating the small GTPase RAC and potent actin nucleation, which were required for the reorganization of the actin cytoskeleton [45]. Allende, M. L. et al. [37], using B cell-specific S1PR1 knockout (B-S1PR1KO) mice, found that S1PR1 provided a signal necessary for the efficient transfer of newly generated immature $B$ cells from the bone marrow to the blood.

Many viewpoints illustrate the phenomenon that lymphocytes internalize in the lymphoid organs is via the CCL21-CCR7 axis [42, 46, 47]. Recent studies illustrated an interesting phenomenon. Collagen expression was negatively regulated by S1PR1 and S1PR3 in human bone marrow-derived mesenchymal stem cells (hMSCs) [48]. The new focus may well be on collagen. One study found that S1PR1 and integrin B4 (ITGB4) were essential for hepatocyte growth factor (HGF)-mediated EC barrier enhancement [49]. In brief, S1P and its receptors function on the macro-environment and microenvironment in the 
body via an "inside-out signaling" mechanism [4]. These cumulative findings proved that S1P is a major regulator of innate and adaptive immunity. At the same time, more questions arose, including whether S1P signaling contributes to inborn or acquired immune diseases, and its longterm effects on thymic education and peripheral lymphoid organ functions.

\section{The role of the SphK/S1P/S1PR1 axis in pathophysiology/pathogenesis}

The SphKs/S1P/S1PRs axis regulates many physiological processes, including pathogenesis or pathophysiology. S1P and its receptors regulate allergic responses, lymphocyte differentiation, endothelial barrier integrity and cytokine and adhesion molecule expression, asthma, rheumatoid arthritis, sepsis, and inflammatory bowel disease [13, 18, 50-53]. IgE receptors on mast cells upregulated SphK1 (and probably SphK2), leading to S1P production. S1P in turn activated its own receptors in an autocrine and/or paracrine manner, which promoted mast cell activation and degranulation [54]. Inhalation of SphK inhibitors improved disease severity in a mouse model of asthma [55]. Histamine released from mast cells stimulated SphK1 and enhanced S1P production by both hematopoietic and nonhematopoietic sources, which was crucial for the clearance of histamine [33]. Camerer, E explained that S1P continuously activated luminal endothelial S1PR1 to maintain tight cell-cell junctions. Following the entry of S1P into the subendothelial space via "leaky" endothelium, dynamic S1PR1 signaling activated abluminal surface S1PRs to close intercellular gaps [50]. Endothelial cell S1PR1 maintained the homeostatic barrier property of the vascular system, and the SphK1/S1P/S1PR1 axis was involved in the restoration of normal vascular barrier integrity during infection and inflammation $[50,56]$.

In response to TNF and other cytokines, SphK1 was activated and translocated to the plasma membrane to catalyze the production of S1P, which was then exported out of the cell by specific transporters to activate its receptors in an autocrine manner. In addition, S1P activated the key inflammatory transcription factor nuclear factor- $\mathrm{kB}$ (NF- $\mathrm{kB})$, which was found to be independent of S1PRs [57-59]. In sepsis, both TLR2 and TLR4 stimulated and upregulated SphK1 and downstream factors such as NF- $\mathrm{kB}$. Therefore, deletion or inhibition of SphK1 prevented sepsis in mouse models of LPS challenge or cecal ligation and puncture [51]. This paved the way for the exploration of SphK1 inhibitors for the treatment of sepsis in humans [11]. In the liver, fibrosis is the common response to chronic liver injury, characterized by excessive deposition of collagen and other components of the extracellular matrix [60,61]. As illustrated above, S1P played a critical role in lymphocyte egress from secondary lymphoid tissues and the thymus. Li C established acute and/or chronic liver injury by carbon tetrachloride injection or bile duct ligation (BDL) in mice, and found that S1P levels in liver tissue and serum were significantly increased [62]. S1P levels in the human fibrotic liver were increased through up-regulation of sphingosine kinase (SphK), irrespective of the etiology of fibrosis that led to liver fibrosis and cirrhosis.

SphK2 may also contribute to mast cell functions [63]. Lai, W.Q found that prior to the development of the clinical symptoms of arthritis, depletion of SphK2 enhanced the production of the pro-inflammatory cytokines IL-6, TNF, and IFN $\gamma$ [64]. SphK2 inhibition alleviated disorders associated with immunosuppression, such as chronic infections and/or cancers [65]. Haberland, M [66] and Glauben, R [67] explained that S1P was bound to and inhibited histone deacetylases 1 (HDAC1) and HDAC2, which may be associated with human diseases such as cancer and inflammation. Furthermore, in Alzheimer's disease, the activity of $\beta$-site APP-cleaving enzyme-1 (BACE1), the rate-limiting enzyme for amyloid$\beta$ peptide $(A \beta)$ production, was modulated by S1P in mouse neurons. Both SphK inhibitors and overexpression of S1P-degrading enzymes decreased BACE1 activity, which reduced $A \beta$ production [68]. Cardiomyocyte ische$\mathrm{mia} /$ reperfusion (I/R) injury is fatal. S1PR1 activation and downstream signaling through Akt enhanced ischemic preconditioning and mammalian cardiomyocyte survival [69]. At the same time, recent studies suggested that S1P agonists FTY720 /SEW2871 could provide protection against stroke and ischemic injury in many tissues [70]. In some studies, SPL inhibitors as well as S1P analogs mediated cardioprotection and prevented sepsis-related tissue injury. High-density lipoprotein (HDL) confers protection against atherosclerosis and heart disease. Recent studies found that S1P mediated HDL's circulation through plasma carriers via its receptors [71]. S1P receptor agonists or antagonists may function in vasodilation, cardioprotection, and survival.

Unlike its positive role in cardiovascular disease, S1P signaling also contributes to carcinogenesis [72]. SphK1 is often upregulated in cancerous tissue, and its overexpression correlates with chemo- and radiation-resistance and poor prognosis [13]. SphK1 promoted cancer growth via multiple mechanisms, including S1P signaling to cancer cells. Sequestering S1P with a specific S1P monoclonal antibody blocked tumorigenesis and tumor angiogenesis in murine xenograft and allograft cancer models [73]. Based on these observations, inhibition of SphK1 reduced tumor growth, angiogenesis and chemoresistance in numerous xenograft models [72, 74].

\section{The role of the SphK/S1P/S1PR1 axis in cancer}

Tumor cells secrete S1P, promoting growth, survival, motility, and metastasis via S1PRs in an autocrine/paracrine 
manner [75-77]. The specific processes are complex, including endothelial adhesion, angiogenesis, and regulation of tumor-stromal interactions [77] (see Table 1).

Interestingly, SPL and S1P phosphatase (SPP) expression were balanced in many human cancers and murine cancer models. In knockout mouse models of human SGPL1, which encodes SPL [78], and through quantitative real-time PCR (Q-PCR) and immunohistochemical analysis, studies found that SPL promoted apoptosis through p53- and p38-dependent pathways. SGPL1 gene which encodes SPL disruption in mouse embryonic fibroblasts increased their resistance to chemotherapeutic agents by upregulating $\mathrm{Bcl}-2$ and $\mathrm{Bcl}-\mathrm{xL}$ [79]. In some cancers, activated SPL affected carcinogenesis to cancer itself under stress [78]. Increasing S1P catabolism or inhibiting S1P biosynthesis could become a new way to treat cancer. In contrast, some studies found that the inhibition of S1P raised secondary malignancy [13]. Targeting S1P signaling may be a double-edged sword.

Studies found that signal transducer and activator of transcription-3 (STAT3) was important in the persistent activation of tumors $[80,81]$. STAT3 is a transcription factor for S1PR1. Enhanced S1PR1 upregulated the expression of IL-6, a pro-inflammatory cytokine crucial for STAT3 activation, inflammatory cell-mediated transformation, and tumor progression [81]. The altered microenvironment is an important factor for malignant progression and metastasis [82].

Aberrant IL-6-JAK-STAT3 signaling in cancer cells is a major mechanism for cancer initiation, development, and progression [82-84]. Lee $\mathrm{H}$ used B16 cells, which have relatively low STAT3 activity and IL-6 expression in cell culture but greatly enhanced STAT3 activity in vivo, achieved at least in part through IL- 6 production by the tumor stromal immune cells $[85,86]$. Kujawski,
M. et al., studied the role of STAT3 in tumor-associated MDSCs and tumor angiogenesis through C57BL/6 naive mice [87]. Chemotactic factors, including IL-6 and IL-10, correlated with STAT3, influencing the whole immune system, including the formation of metastatic niches [88, 89]. Studies have found minute differences in Jak somatotypes for STAT3, and various animal models were used to reveal the particular passageways in the microenvironment $[29,88,90]$.

Several seminal studies have documented the importance of myeloid cells in providing a sanctuary for tumor cell adhesion, survival, and secondary site colonization [91, 92]. Myeloid cells mobilized and produced chemokines and other molecules in response to the tumor environment, thereby promoting cancer progression [93, 94]. However, the role of myeloid cells in forming a sanctuary for tumor cells in distant organs prior to tumor cell arrival/outgrowth remains unknown [91, 92]. Targeting STAT3/S1PR1 signaling in immune cells could reduce STAT3 activity and myeloid cell infiltration in future metastatic sites [91, 95, 96]. S1PR1-STAT3 in tumor cells and myeloid cells orchestrated premetastatic niche formation, and persistent STAT3 signaling in myeloid cells could increase their proliferation and survival, as well as that of other stromal cells at future metastatic sites [88].

\section{Targeting therapies toward the SphK/S1P/S1PR1 axis}

In many types of cancer and in some inflammatory disease, SphK1 is overexpressed [18]. SphK1 expression, enzymatic activity, and subsequent S1P production were stimulated by TNF- $\alpha$, as well as by a host of other inflammatory signaling molecules, including IL-1 $\beta$, IFN- $\gamma$, IgE, and C5a [97]. SphK1 is accordingly a primary target

Table 1 SphK/S1P/S1PR1 axis in cancer

\begin{tabular}{|c|c|c|c|}
\hline Which type & Main cancer/bad outcomes & Mechanism/causes & References \\
\hline \multirow[t]{4}{*}{ 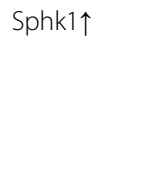 } & Breast cancer & Hemangiogenesis & {$[76,77,81,85]$} \\
\hline & Glioma & Lymphangiogenesis & \\
\hline & B17 melanoma malignance & $\mathrm{IL}-17 \uparrow \rightarrow \mathrm{LL}-6-\mathrm{Stat} 3 \uparrow \rightarrow$ stat $3 \uparrow$ & \\
\hline & MB49 bladder malignance & & \\
\hline \multirow[t]{3}{*}{ SphK2 $\downarrow$} & Colitis-associated tumorigenesis & SphK1 $\uparrow$ & {$[80]$} \\
\hline & & SphK1/S1P/S1PR1 axis $\uparrow$ & \\
\hline & & NF-KB/STAT3 $\uparrow$ & \\
\hline \multirow[t]{3}{*}{$\mathrm{S} 1 \mathrm{P} \uparrow$} & Colon cancer & S1P lyase $\downarrow \rightarrow$ p53-, p38-dependent pathways $\uparrow$ & {$[78,79]$} \\
\hline & Melanoma & SGPL1 gene $\uparrow \rightarrow$ S1P lyase disruption $\uparrow \rightarrow \mathrm{BCl}-2$, Bcl-xL dependent pathways & \\
\hline & Resistance to chemotherapy & & \\
\hline \multirow[t]{3}{*}{ 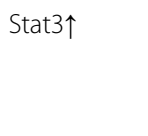 } & Melanoma & RelA acetylation $\rightarrow \mathrm{NF}-\mathrm{kB} \uparrow$ & {$[86,87,89]$} \\
\hline & Myeloid cell-dependent tumor & BRAF-MAPK $\uparrow$ & \\
\hline & A2058 tumor cells malignance & VEGF/bFGF $\rightarrow$ tube formation & \\
\hline
\end{tabular}


for the development of therapeutic intervention strategies [98]. Safingol, a first-generation SphK inhibitor, had some achievements in phase 1 clinical trials [99] (see Table 2).

SK1-I,(2R,3S,4E)-N-methyl-5-(4'-pentylphenyl)-2-aminopent-4-ene-1,3-diol, designated SK1-I (BML-258), markedly reduced the growth of AML xenograft tumors and acute myelogenous leukemia by affecting multiple survival signaling pathways [100]. Kapitonov found that SK1-I reduced the growth, migration, and invasion of several glioblastoma multiforme (GBM) cell lines by using SphK1 inhibition. This function of SK1-I was attributed to the suppression of Akt activation, and the subsequent interruption of signaling through the Akt pathway, which is upregulated in the majority of glioblastomas [99]. Meantime, a combination of SphK1 inhibitors and cisplatin could be used to treat patients and provide some degree of disease regression [99].

SKI-II enhanced the resistance to apoptosis in human non-small cell lung cancer via the PI3K/Akt/NF-kB pathway [101]. Interestingly, SKI-II seemed to be relevant to hormone-associated diseases. SKI-II dose-dependently decreased estrogen-stimulated estrogen response element transcriptional activity and diminished the messenger RNA (mRNA) levels of the estrogen receptor (ER)-regulated genes progesterone receptor and steroid derived factor-1. Therefore, blocking estrogen signaling was prospective in targeted breast cancer therapy [102]. Another SK1 inhibitor, Ski (2-(p-hydroxyanilino)-4-(p-chlorophenyl)thiazole), induced the proteasomal degradation of SK1 in human androgen-sensitive LNCaP prostate cancer cells [103]. Further research is needed to illustrate the specific relationship between Ski inhibitors and hormone-mediated diseases. Cancer studies with SphK2 are less common than those with SphK1. Therefore, illustrating the possibility of SphK2 associated disease is difficult. In an early study, Van Brocklyn JR found that RNA interference of SphK2 expression inhibited glioblastoma cell proliferation more potently than did SphK1 knockdown [104]. One study found that in xenograft nude mice, SphK2-deficient tumors displayed a pronounced anti-tumor phenotype, including increased pro-inflammatory markers NO, TNF-alpha, and IL-12 [105]. A subsequent study proposed that ABC294640, a selective inhibitor of SphK1 that modulated the S1P level, could antagonize cancers such as breast cancer and ovarian cancer $[106,107]$. The mechanism may be via the inhibition of tumor cell migration, concomitant with loss of microfilaments [98]. Correspondingly, we could develop clinical or intervention strategies to cure or ease disease.

FTY720, an immunosuppressive small molecule drug, bound to and eventually induced the internalization and degradation of one out of the five known S1P cell surface receptors, which prevented its function as a sensor of S1P gradients [108]. FTY720, which is phosphorylated in vivo by SphK2, could prevent $\mathrm{T}$ and $\mathrm{B}$ cell egress from lymph nodes (LN) and Peyer's patches [109], as the S1P/ S1PR axis is also important for B cell migration through

Table 2 Different drugs produce varied function in cancer

\begin{tabular}{|c|c|c|c|c|}
\hline Drugs & Type & Main function & Functional mechanism & References \\
\hline \multirow[t]{3}{*}{ SK1-I } & \multirow[t]{3}{*}{ Inhibitor of SphKs } & Leukemia & $\mathrm{BCl}-2$ & \multirow{3}{*}{$\begin{array}{l}{[77,100,} \\
103]\end{array}$} \\
\hline & & Breast cancer & ERK1/2 and Akt & \\
\hline & & Prostate cancer & MCF-7/MCF-7 HER2 & \\
\hline \multirow[t]{3}{*}{ SKI-II } & \multirow[t]{3}{*}{ Inhibitor of SphKs } & \multirow{2}{*}{$\begin{array}{l}\text { Human non-small cell } \\
\text { lung cancer }\end{array}$} & PI3K/Akt/ NF-KB & \multirow[t]{3}{*}[101,102]{} \\
\hline & & & Estrogen receptor-regulated genes & \\
\hline & & Breast cancer therapy & SDF-1 & \\
\hline \multirow[t]{4}{*}{ Safingol } & \multirow[t]{4}{*}{ Putative inhibitor of SphK } & Glioblastomas & \multirow[t]{4}{*}{ A Phase I Clinical medicine } & \multirow[t]{4}{*}{ [99] } \\
\hline & & Colorectal tumor & & \\
\hline & & Adrenal cortical carcinoma & & \\
\hline & & Sarcoma & & \\
\hline \multirow[t]{2}{*}{ ABC294640 } & \multirow[t]{2}{*}{ Selective inhibitor of SphK1 } & Breast cancer & Inhibition of tumor cell migration & \multirow{2}{*}{$\begin{array}{l}{[98,106} \\
107]\end{array}$} \\
\hline & & Ovarian cancer & Loss of microfilaments & \\
\hline \multirow[t]{5}{*}{ FTY720 } & Sphingosine analog & $\begin{array}{l}\text { Peripheral blood stem cell } \\
\text { (PBSC) transplantation }\end{array}$ & $\begin{array}{l}\text { Internalization and degradation } \\
\text { of S1P receptor } 1-5\end{array}$ & $\begin{array}{l}{[35,38,40,} \\
108,109]\end{array}$ \\
\hline & \multirow{4}{*}{$\begin{array}{l}\text { Immunosuppressive small molecule } \\
\text { drug }\end{array}$} & Anti-tumor in many tissues & Bone mineral metabolism & \\
\hline & & Needs further research & $\begin{array}{l}\text { Enhanced AMD3100-mediated HSC } \\
\text { mobilization }\end{array}$ & \\
\hline & & \multirow[t]{2}{*}{$\begin{array}{l}\text { Relieved ovariectomy-induced } \\
\text { osteoporosis }\end{array}$} & $\begin{array}{l}\text { Prevent } T \text { and } B \text { cell egress from } \\
\text { lymph nodes }\end{array}$ & \\
\hline & & & S1PR1 $\uparrow \rightarrow$ SDF-1 sensitivity $\uparrow \rightarrow$ CXCR4 $\uparrow$ & \\
\hline
\end{tabular}


the lymph node follicle [18]. FTY720, an agonist of S1P, has been approved for the treatment of multiple sclerosis. Its ligands were for all of the S1PRs, except S1PR2. The clinical efficacy of FTY720 has been attributed to its ability to promote the retention of naive $\mathrm{T}$ cells and central memory $\mathrm{T}$ cells (including autoreactive $\mathrm{T}_{\mathrm{H}} 17$ cells) in lymph nodes, preventing terminally differentiated effector $\mathrm{T}$ cells and effector memory $\mathrm{T}$ cells from entering the central nervous system and driving pathological responses. On the other hand, FTY720 minimally affected peripheral effector memory $\mathrm{T}$ cells, which were important for protection against infection [109-111].

\section{Conclusions}

Immune microenvironment is a changeable zone in which large amounts of molecules, metabolites, and electrochemical substances weave mixed network. The function of sphingosine not only existed in its relation with other sterols in chemistry but it also causes huge biological influences through SphKs/S1P/S1PR1 axis, including physiological/pathological processes, e.g., hemopoietic system, lymphocytes internalization, allergic response, ischemia reperfusion injury, inflammatory bowel disease, and heterogeneity of carcinoma. In our retrospective study, many researchers illustrated SphKs/S1P/S1PR1's functions via "inside-out signaling", and some targeted drugs focused on SphKs/S1P/S1PR1 axis impact abovementioned physiological or pathological processes (like PI3K/Akt/NF-kB pathway). Although it is difficult to keep pace with the rapidly moving target of S1P in the immune system, the development of a second generation of drugs with improved specificity and efficacy will provide new treatment strategies for these inflammatory disorders and, moreover, will enhance our understanding of how this "simple" sphingolipid metabolite functions both the inside and outside of cells.

\section{Competing interests}

The authors declare that they have no competing interests.

\section{Authors' contributions}

$\sqcup J$ searched and collected related papers, extracted the research information from those papers, and drafted the manuscript. WRL and MXT revised the manuscript. JF checked the structure of the manuscript. All the authors read and approved the final manuscript.

\section{Acknowledgements}

\section{Financial support}

This work was supported by the grants from National Natural Science Foundation of China (No.81272389, 81472674).

\section{Author details}

'Department of Liver Surgery, Liver Cancer Institute, Zhongshan Hospital, Fudan University; Key Laboratory of Carcinogenesis and Cancer Invasion of Ministry of Education, 180 FengLin Road, Shanghai 200032, China. ${ }^{2}$ Institutes of Biomedical Sciences, Fudan University, Shanghai, People's Republic of China.
Received: 30 October 2015 Accepted: 21 April 2016

Published online: 29 April 2016

\section{References}

1. Carter HE, Haines WJ, et al. Biochemistry of the sphingolipides; preparation of sphingolipides from beef brain and spinal cord. J Biol Chem. 1947;169:77-82.

2. Fyrst H, Saba JD. An update on sphingosine-1-phosphate and other sphingolipid mediators. Nat Chem Biol. 2010;6:489-97.

3. Mizugishi K, Yamashita T, Olivera A, Miller GF, Spiegel S, Proia RL. Essential role for sphingosine kinases in neural and vascular development. Mol Cell Biol. 2005:25:11113-21.

4. Spiegel S, Milstien S. Sphingosine-1-phosphate: an enigmatic signalling lipid. Nat Rev Mol Cell Biol. 2003;4:397-407.

5. Rivera J, Proia RL, Olivera A. The alliance of sphingosine-1-phosphate and its receptors in immunity. Nat Rev Immunol. 2008:8:753-63.

6. Alvarez SE, Milstien S, Spiegel S. Autocrine and paracrine roles of sphingosine-1-phosphate. Trends Endocrinol Metab. 2007:18:300-7.

7. Hait NC, Bellamy A, Milstien S, Kordula T, Spiegel S. Sphingosine kinase type 2 activation by ERK-mediated phosphorylation. J Biol Chem. 2007;282: 12058-65.

8. Don AS, Rosen H. A lipid binding domain in sphingosine kinase 2. Biochem Biophys Res Commun. 2009;380:87-92.

9. Hait NC, Allegood J, Maceyka M, Strub GM, Harikumar KB, Singh SK, Luo C, Marmorstein R, Kordula T, Milstien S, Spiegel S. Regulation of histone acetylation in the nucleus by sphingosine-1-phosphate. Science. 2009:325:1254-7.

10. Alvarez SE, Harikumar KB, Hait NC, Allegood J, Strub GM, Kim EY, Maceyka M, Jiang H, Luo C, Kordula T, Milstien S, Spiegel S. Sphingosine-1-phosphate is a missing cofactor for the E3 ubiquitin ligase TRAF2. Nature. 2010;465:1084-8.

11. Puneet $P$, Yap CT, Wong L, Lam Y, Koh DR, Moochhala S, Pfeilschifter J, Huwiler A, Melendez AJ. SphK1 regulates proinflammatory responses associated with endotoxin and polymicrobial sepsis. Science. 2010;328:1290-4.

12. Strub GM, Paillard M, Liang J, Gomez L, Allegood JC, Hait NC, Maceyka M, Price MM, Chen Q, Simpson DC, Kordula T, Milstien S, Lesnefsky EJ, Spiegel S. Sphingosine-1-phosphate produced by sphingosine kinase 2 in mitochondria interacts with prohibitin 2 to regulate complex IV assembly and respiration. FASEB J. 2011;25:600-12.

13. Shida D, Takabe K, Kapitonov D, Milstien S, Spiegel S. Targeting SphK1 as a new strategy against cancer. Curr Drug Targets. 2008;9:662-73.

14. Pappu R, Schwab SR, Cornelissen I, Pereira JP, Regard JB, Xu Y, Camerer E, Zheng YW, Huang Y, Cyster JG, Coughlin SR. Promotion of lymphocyte egress into blood and lymph by distinct sources of sphingosine-1-phosphate. Science. 2007;316:295-8.

15. Merrill Jr AH, Wang MD, Park M, Sullards MC. (Glyco)sphingolipidology: an amazing challenge and opportunity for systems biology. Trends Biochem Sci. 2007;32:457-68.

16. Kirby RJ, Jin Y, Fu J, Cubillos J, Swertfeger D, Arend LJ. Dynamic regulation of sphingosine-1-phosphate homeostasis during development of mouse metanephric kidney. Am J Physiol Renal Physiol. 2009;296:F634-641.

17. Peter BF, Lidington D, Harada A, Bolz HJ, Vogel L, Heximer S, Spiegel S, Pohl $\mathrm{U}$, Bolz SS. Role of sphingosine-1-phosphate phosphohydrolase 1 in the regulation of resistance artery tone. Circ Res. 2008;103:315-24.

18. Spiegel S, Milstien $\mathrm{S}$. The outs and the ins of sphingosine-1-phosphate in immunity. Nat Rev Immunol. 2011;11:403-15.

19. Takabe K, Kim RH, Allegood JC, Mitra P, Ramachandran S, Nagahashi M, Harikumar KB, Hait NC, Milstien S, Spiegel S. Estradiol induces export of sphingosine 1-phosphate from breast cancer cells via ABCC1 and ABCG2.J Biol Chem. 2010;285:10477-86.

20. Sato K, Malchinkhuu E, Horiuchi Y, Mogi C, Tomura H, Tosaka M, Yoshimoto Y, Kuwabara A, Okajima F. Critical role of ABCA1 transporter in sphingosine 1-phosphate release from astrocytes. J Neurochem. 2007;103:2610-9.

21. Mitra P, Oskeritzian CA, Payne SG, Beaven MA, Milstien S, Spiegel S. Role of ABCC1 in export of sphingosine-1-phosphate from mast cells. Proc Natl Acad Sci U S A. 2006;103:16394-9.

22. Serra M, Saba JD. Sphingosine 1-phosphate lyase, a key regulator of sphingosine 1-phosphate signaling and function. Adv Enzym Regul. 2010;50:349-62.

23. Mukhopadhyay D, Howell KS, Riezman H, Capitani G. Identifying key residues of sphinganine-1-phosphate lyase for function in vivo and in vitro. J Biol Chem. 2008;283:20159-69. 
24. Hagen N, Van Veldhoven PP, Proia RL, Park H, Merrill Jr AH, van Echten-Deckert G. Subcellular origin of sphingosine 1-phosphate is essential for its toxic effect in lyase-deficient neurons. J Biol Chem. 2009;284:11346-53.

25. Vogel P, Donoviel MS, Read R, Hansen GM, Hazlewood J, Anderson SJ, Sun W, Swaffield J, Oravecz T. Incomplete inhibition of sphingosine 1-phosphate lyase modulates immune system function yet prevents early lethality and non-lymphoid lesions. PLoS One. 2009;4:e4112.

26. Bai $A, H u H$, Yeung $M$, Chen J. Kruppel-like factor 2 controls $T$ cell trafficking by activating L-selectin (CD62L) and sphingosine-1-phosphate receptor 1 transcription. J Immunol. 2007:178:7632-9.

27. Rosen H, Gonzalez-Cabrera PJ, Sanna MG, Brown S. Sphingosine 1-phosphate receptor signaling. Annu Rev Biochem. 2009;78:743-68.

28. Willinger T, Ferguson SM, Pereira JP, De Camilli P, Flavell RA. Dynamin 2-dependent endocytosis is required for sustained S1PR1 signaling. J Exp Med. 2014;211:685-700.

29. Priceman SJ, Shen S, Wang L, Deng J, Yue C, Kujawski M, Yu H. S1PR1 is crucial for accumulation of regulatory T cells in tumors via STAT3. Cell Rep. 2014;6:992-9.

30. Zhang H, Desai NN, Olivera A, Seki T, Brooker G, Spiegel S. Sphingosine-1phosphate, a novel lipid, involved in cellular proliferation. J Cell Biol. 1991. 114:155-67.

31. Pebay A, Wong RC, Pitson SM, Wolvetang EJ, Peh GS, Filipczyk A, Koh KL, Tellis I, Nguyen LT, Pera MF. Essential roles of sphingosine-1-phosphate and plateletderived growth factor in the maintenance of human embryonic stem cells. Stem Cells. 2005;23:1541-8.

32. Skoura A, Hla T. Lysophospholipid receptors in vertebrate development, physiology, and pathology. J Lipid Res. 2009;50(Suppl):S293-298.

33. Olivera A, Eisner C, Kitamura Y, Dillahunt S, Allende L, Tuymetova G, Watford W, Meylan F, Diesner SC, Li L, Schnermann J, Proia RL, Rivera J. Sphingosine kinase 1 and sphingosine-1-phosphate receptor 2 are vital to recovery from anaphylactic shock in mice. J Clin Invest. 2010;120:1429-40.

34. Ratajczak MZ, Lee H, Wysoczynski M, Wan W, Marlicz W, Laughlin MJ, Kucia M, Janowska-Wieczorek A, Ratajczak J. Novel insight into stem cell mobilization-plasma sphingosine-1-phosphate is a major chemoattractant that directs the egress of hematopoietic stem progenitor cells from the bone marrow and its level in peripheral blood increases during mobilization due to activation of complement cascade/membrane attack complex. Leukemia. 2010;24:976-85.

35. Kimura T, Boehmler AM, Seitz G, Kuci S, Wiesner T, Brinkmann V, Kanz L, Mohle R. The sphingosine 1-phosphate receptor agonist FTY720 supports CXCR4-dependent migration and bone marrow homing of human CD34+ progenitor cells. Blood. 2004;103:4478-86.

36. Massberg S, Schaerli P, Knezevic-Maramica I, Kollnberger M, Tubo N, Moseman EA, Huff IV, Junt T, Wagers AJ, Mazo IB, von Andrian UH. Immunosurveillance by hematopoietic progenitor cells trafficking through blood, lymph, and peripheral tissues. Cell. 2007;131:994-1008.

37. Allende ML, Tuymetova G, Lee BG, Bonifacino E, Wu YP, Proia RL. S1P1 receptor directs the release of immature $B$ cells from bone marrow into blood. J Exp Med. 2010;207:1113-24.

38. Juarez JG, Harun N, Thien M, Welschinger R, Baraz R, Pena AD, Pitson SM, Rettig M, DiPersio JF, Bradstock KF, Bendall LJ. Sphingosine-1-phosphate facilitates trafficking of hematopoietic stem cells and their mobilization by CXCR4 antagonists in mice. Blood. 2012;119:707-16.

39. Kobayashi N, Yamaguchi A, Nishi T. Characterization of the ATP-dependent sphingosine 1-phosphate transporter in rat erythrocytes. J Biol Chem. 2009;284:21192-200.

40. Ishii M, Egen JG, Klauschen F, Meier-Schellersheim M, Saeki Y, Vacher J, Proia RL, Germain RN. Sphingosine-1-phosphate mobilizes osteoclast precursors and regulates bone homeostasis. Nature. 2009;458:524-8.

41. Pereira JP, XU Y, Cyster JG. A role for S1P and S1P1 in immature-B cell egress from mouse bone marrow. PLoS One. 2010;5:e9277.

42. Pham TH, Okada T, Matloubian M, Lo CG, Cyster JG. S1P1 receptor signaling overrides retention mediated by $\mathrm{G}$ alpha i-coupled receptors to promote $\mathrm{T}$ cell egress. Immunity. 2008;28:122-33.

43. Bankovich AJ, Shiow LR, Cyster JG. CD69 suppresses sphingosine 1-phosophate receptor-1 (S1P1) function through interaction with membrane helix 4. J Biol Chem. 2010;285:22328-37.

44. Cinamon G, Zachariah MA, Lam OM, Foss Jr FW, Cyster JG. Follicular shuttling of marginal zone B cells facilitates antigen transport. Nat Immunol. 2008;9:54-62.

45. Faroudi M, Hons M, Zachacz A, Dumont C, Lyck R, Stein JV, Tybulewicz VL. Critical roles for Rac GTPases in T-cell migration to and within lymph nodes. Blood. 2010;116:5536-47.
46. Thangada S, Khanna KM, Blaho VA, Oo ML, Im DS, Guo C, Lefrancois L, Hla T. Cell-surface residence of sphingosine 1-phosphate receptor 1 on lymphocytes determines lymphocyte egress kinetics. J Exp Med. 2010;207: 1475-83.

47. Schwab SR, Cyster JG. Finding a way out: lymphocyte egress from lymphoid organs. Nat Immunol. 2007:8:1295-301.

48. Chang N, Xiu L, Li L. Sphingosine 1-phosphate receptors negatively regulate collagen type I/III expression in human bone marrow-derived mesenchymal stem cell. J Cell Biochem. 2014;115:359-67.

49. Ephstein $Y$, Singleton PA, Chen W, Wang L, Salgia R, Kanteti P, Dudek SM, Garcia JG, Jacobson JR. Critical role of S1PR1 and integrin beta4 in HGF/C-Metmediated increases in vascular integrity. J Biol Chem. 2013;288:2191-200.

50. Camerer E, Regard JB, Cornelissen I, Srinivasan Y, Duong DN, Palmer D, Pham TH, Wong JS, Pappu R, Coughlin SR. Sphingosine-1-phosphate in the plasma compartment regulates basal and inflammation-induced vascular leak in mice. J Clin Invest. 2009;119:1871-9.

51. Niessen F, Schaffner F, Furlan-Freguia C, Pawlinski R, Bhattacharjee G, Chun J Derian CK, Andrade-Gordon P, Rosen H, Ruf W. Dendritic cell PAR1-S1P3 signalling couples coagulation and inflammation. Nature. 2008:452:654-8.

52. Pyne NJ, Pyne S. Sphingosine 1-phosphate and cancer. Nat Rev Cancer. 2010;10:489-503.

53. Karin M. The IkappaB kinase - a bridge between inflammation and cancer. Cell Res. 2008;18:334-42.

54. Kawahara A, Nishi T, Hisano Y, Fukui H, Yamaguchi A, Mochizuki N. The sphingolipid transporter spns2 functions in migration of zebrafish myocardial precursors. Science. 2009;323:524-7.

55. Nishiuma T, Nishimura $Y$, Okada T, Kuramoto E, Kotani $Y$, Jahangeer $S$, Nakamura S. Inhalation of sphingosine kinase inhibitor attenuates airway inflammation in asthmatic mouse model. Am J Physiol Lung Cell Mol Physiol. 2008;294:L1085-1093.

56. Niessen F, Furlan-Freguia C, Fernandez JA, Mosnier LO, Castellino FJ, Weiler H, Rosen $\mathrm{H}$, Griffin JH, Ruf W. Endogenous EPCR/aPC-PAR1 signaling prevents inflammation-induced vascular leakage and lethality. Blood. 2009;113:2859-66.

57. Baker DA, Barth J, Chang R, Obeid LM, Gilkeson GS. Genetic sphingosine kinase 1 deficiency significantly decreases synovial inflammation and joint erosions in murine TNF-alpha-induced arthritis. J Immunol. 2010;185:2570-9.

58. Pitson SM, Moretti PA, Zebol JR, Lynn HE, Xia P, Vadas MA, Wattenberg BW. Activation of sphingosine kinase 1 by ERK1/2-mediated phosphorylation. EMBO J. 2003;22:5491-500

59. Takabe K, Paugh SW, Milstien S, Spiegel S. "Inside-out" signaling of sphingosine-1-phosphate: therapeutic targets. Pharmacol Rev. 2008;60:181-95.

60. Friedman SL. Molecular regulation of hepatic fibrosis, an integrated cellular response to tissue injury. J Biol Chem. 2000;275:2247-50.

61. Friedman SL. Mechanisms of hepatic fibrogenesis. Gastroenterology. 2008; 134:1655-69.

62. Li C, Zheng S, You H, Liu X, Lin M, Yang L, Li L. Sphingosine 1-phosphate (S1P)/S1P receptors are involved in human liver fibrosis by action on hepatic myofibroblasts motility. J Hepatol. 2011;54:1205-13.

63. Olivera A, Mizugishi K, Tikhonova A, Ciaccia L, Odom S, Proia RL, Rivera J. The sphingosine kinase-sphingosine-1-phosphate axis is a determinant of mast cell function and anaphylaxis. Immunity. 2007;26:287-97.

64. Lai WQ, Irwan AW, Goh HH, Melendez AJ, Mclnnes IB, Leung BP. Distinct roles of sphingosine kinase 1 and 2 in murine collagen-induced arthritis. J Immunol. 2009;183:2097-103.

65. Samy ET, Meyer CA, Caplazi P, Langrish CL, Lora JM, Bluethmann H, Peng SL. Cutting edge: Modulation of intestinal autoimmunity and IL-2 signaling by sphingosine kinase 2 independent of sphingosine 1-phosphate. J Immunol. 2007;179:5644-8.

66. Haberland M, Montgomery RL, Olson EN. The many roles of histone deacetylases in development and physiology: implications for disease and therapy. Nat Rev Genet. 2009;10:32-42.

67. Glauben R, Sonnenberg E, Zeitz M, Siegmund B. HDAC inhibitors in models of inflammation-related tumorigenesis. Cancer Lett. 2009;280:154-9.

68. Takasugi N, Sasaki T, Suzuki K, Osawa S, Isshiki H, Hori Y, Shimada N, Higo T, Yokoshima S, Fukuyama T, Lee VM, Trojanowski JQ, Tomita T, Iwatsubo T. BACE1 activity is modulated by cell-associated sphingosine-1-phosphate. J Neurosci. 2011;31:6850-7.

69. Means CK, Xiao CY, Li Z, Zhang T, Omens JH, Ishii I, Chun J, Brown JH. Sphingosine 1-phosphate S1P2 and S1P3 receptor-mediated Akt activation protects against in vivo myocardial ischemia-reperfusion injury. Am J Phys Heart Circ Phys. 2007;292:H2944-2951. 
70. Hasegawa Y, Suzuki H, Sozen T, Rolland W, Zhang JH. Activation of sphingosine 1-phosphate receptor-1 by FTY720 is neuroprotective after ischemic stroke in rats. Stroke. 2010;41:368-74.

71. Sattler K, Levkau B. Sphingosine-1-phosphate as a mediator of high-density lipoprotein effects in cardiovascular protection. Cardiovasc Res. 2009;82:201-11.

72. Kunkel GT, Maceyka M, Milstien S, Spiegel S. Targeting the sphingosine-1phosphate axis in cancer, inflammation and beyond. Nat Rev Drug Discov. 2013;12:688-702.

73. Visentin B, Vekich JA, Sibbald BJ, Cavalli AL, Moreno KM, Matteo RG, Garland WA, Lu Y, Yu S, Hall HS, Kundra V, Mills GB, Sabbadini RA. Validation of an anti-sphingosine-1-phosphate antibody as a potential therapeutic in reducing growth, invasion, and angiogenesis in multiple tumor lineages. Cancer Cell. 2006;9:225-38.

74. Guan H, Song L, Cai J, Huang Y, Wu J, Yuan J, Li J, Li M. Sphingosine kinase 1 regulates the Akt/FOXO3a/Bim pathway and contributes to apoptosis resistance in glioma cells. PLoS One. 2011;6:e19946.

75. Sultan A, Ling B, Zhang H, Ma B, Michel D, Alcorn J, Yang J. Synergistic effect between sphingosine-1-phosphate and chemotherapy drugs against human brain-metastasized breast cancer MDA-MB-361 cells. J Cancer. 2013; 4:315-9.

76. Nagahashi M, Ramachandran S, Kim EY, Allegood JC, Rashid OM, Yamada A, Zhao R, Milstien S, Zhou H, Spiegel S, Takabe K. Sphingosine-1-phosphate produced by sphingosine kinase 1 promotes breast cancer progression by stimulating angiogenesis and lymphangiogenesis. Cancer Res. 2012;72:726-35.

77. Anelli V, Gault CR, Snider AJ, Obeid LM. Role of sphingosine kinase-1 in paracrine/transcellular angiogenesis and lymphangiogenesis in vitro. FASEB J. 2010;24:2727-38.

78. Oskouian B, Sooriyakumaran P, Borowsky AD, Crans A, Dillard-Telm L, Tam YY, Bandhuvula P, Saba JD. Sphingosine-1-phosphate lyase potentiates apoptosis via p53- and p38-dependent pathways and is down-regulated in colon cancer. Proc Natl Acad Sci U S A. 2006;103:17384-9.

79. Colie S, Van Veldhoven PP, Kedjouar B, Bedia C, Albinet V, Sorli SC, Garcia V, Djavaheri-Mergny M, Bauvy C, Codogno P, Levade T, Andrieu-Abadie N. Disruption of sphingosine 1-phosphate lyase confers resistance to chemotherapy and promotes oncogenesis through $\mathrm{BCl}-2 / \mathrm{BCl}-\mathrm{xL}$ upregulation. Cancer Res. 2009;69:9346-53.

80. Liang J, Nagahashi M, Kim EY, Harikumar KB, Yamada A, Huang WC, Hait NC, Allegood JC, Price MM, Avni D, Takabe K, Kordula T, Milstien S, Spiegel S. Sphingosine-1-phosphate links persistent STAT3 activation, chronic intestinal inflammation, and development of colitis-associated cancer. Cancer Cell. 2013;23:107-20.

81. Lee H, Deng J, Kujawski M, Yang C, Liu Y, Herrmann A, Kortylewski M, Horne D, Somlo G, Forman S, Jove R, Yu H. STAT3-induced S1PR1 expression is crucial for persistent STAT3 activation in tumors. Nat Med. 2010;16:1421-8.

82. Rebouissou S, Amessou M, Couchy G, Poussin K, Imbeaud S, Pilati C, Izard T, Balabaud C, Bioulac-Sage P, Zucman-Rossi J. Frequent in-frame somatic deletions activate gp130 in inflammatory hepatocellular tumours. Nature. 2009;457:200-4.

83. Yu H, Kortylewski M, Pardoll D. Crosstalk between cancer and immune cells: role of STAT3 in the tumour microenvironment. Nat Rev Immunol. 2007;7:41-51.

84. Yu H, Pardoll D, Jove R. STATs in cancer inflammation and immunity: a leading role for STAT3. Nat Rev Cancer. 2009;9:798-809.

85. Wang $L$, Yi T, Kortylewski M, Pardoll DM, Zeng D, Yu H. IL-17 can promote tumor growth through an IL-6-Stat3 signaling pathway. J Exp Med. 2009; 206:1457-64.

86. Lee H, Herrmann A, Deng JH, Kujawski M, Niu G, Li Z, Forman S, Jove R, Pardoll DM, Yu H. Persistently activated Stat3 maintains constitutive NFkappaB activity in tumors. Cancer Cell. 2009;15:283-93.

87. Kujawski M, Kortylewski M, Lee H, Herrmann A, Kay H, Yu H. Stat3 mediates myeloid cell-dependent tumor angiogenesis in mice. J Clin Invest. 2008;118:3367-77.

88. Deng J, Liu Y, Lee H, Herrmann A, Zhang W, Zhang C, Shen S, Priceman SJ, Kujawski M, Pal SK, Raubitschek A, Hoon DS, Forman S, Figlin RA, Liu J, Jove $\mathrm{R}$, YU H. S1PR1-STAT3 signaling is crucial for myeloid cell colonization at future metastatic sites. Cancer Cell. 2012;21:642-54.

89. Sumimoto $H$, Imabayashi $F$, Iwata $T$, Kawakami $Y$. The BRAF-MAPK signaling pathway is essential for cancer-immune evasion in human melanoma cells. J Exp Med. 2006;203:1651-6.

90. Munitz A, McBride ML, Bernstein JS, Rothenberg ME. A dual activation and inhibition role for the paired immunoglobulin-like receptor $B$ in eosinophils. Blood. 2008;111:5694-703.
91. Erler JT, Bennewith KL, Cox TR, Lang G, Bird D, Koong A, Le QT, Giaccia AJ. Hypoxia-induced lysyl oxidase is a critical mediator of bone marrow cell recruitment to form the premetastatic niche. Cancer Cell. 2009;15:35-44.

92. Psaila B, Lyden D. The metastatic niche: adapting the foreign soil. Nat Rev Cancer. 2009;9:285-93.

93. Biswas SK, Mantovani A. Macrophage plasticity and interaction with lymphocyte subsets: cancer as a paradigm. Nat Immunol. 2010;11:889-96.

94. Pollard JW. Tumour-educated macrophages promote tumour progression and metastasis. Nat Rev Cancer. 2004:4:71-8.

95. Kaplan RN, Riba RD, Zacharoulis S, Bramley AH, Vincent L, Costa C, MacDonald DD, Jin DK, Shido K, Kerns SA, Zhu Z, Hicklin D, Wu Y, Port JL, Altorki N, Port ER, Ruggero D, Shmelkov SV, Jensen KK, Rafii S, Lyden D. VEGFR1-positive haematopoietic bone marrow progenitors initiate the premetastatic niche. Nature. 2005;438:820-7.

96. Kim S, Takahashi H, Lin WW, Descargues P, Grivennikov S, Kim Y, Luo JL Karin M. Carcinoma-produced factors activate myeloid cells through TLR2 to stimulate metastasis. Nature. 2009;457:102-6.

97. Snider AJ, Orr Gandy KA, Obeid LM. Sphingosine kinase: Role in regulation of bioactive sphingolipid mediators in inflammation. Biochimie. 2010;92:707-15.

98. French KJ, Zhuang Y, Maines LW, Gao P, Wang W, Beljanski V, Upson JJ, Green CL, Keller SN, Smith CD. Pharmacology and antitumor activity of ABC294640, a selective inhibitor of sphingosine kinase-2. J Pharmacol Exp Ther. 2010;333:129-39.

99. Dickson MA, Carvajal RD, Merrill Jr AH, Gonen M, Cane LM, Schwartz GK. A phase I clinical trial of safingol in combination with cisplatin in advanced solid tumors. Clin Cancer Res. 2011;17:2484-92.

100. Paugh SW, Paugh BS, Rahmani M, Kapitonov D, Almenara JA, Kordula T, Milstien S, Adams JK, Zipkin RE, Grant S, Spiegel S. A selective sphingosine kinase 1 inhibitor integrates multiple molecular therapeutic targets in human leukemia. Blood. 2008;112:1382-91.

101. Song L, Xiong H, Li J, Liao W, Wang L, Wu J, Li M. Sphingosine kinase-1 enhances resistance to apoptosis through activation of PI3K/Akt/NF-kappaB pathway in human non-small cell lung cancer. Clin Cancer Res. 2011;17:1839-49.

102. Antoon JW, Meacham WD, Bratton MR, Slaughter EM, Rhodes LV, Ashe HB, Wiese TE, Burow ME, Beckman BS. Pharmacological inhibition of sphingosine kinase isoforms alters estrogen receptor signaling in human breast cancer. J Mol Endocrinol. 2011:46:205-16.

103. Loveridge C, Tonelli F, Leclercq T, Lim KG, Long JS, Berdyshev E, Tate RJ, Natarajan V, Pitson SM, Pyne NJ, Pyne S. The sphingosine kinase 1 inhibitor 2-(p-hydroxyanilino)-4-(p-chlorophenyl)thiazole induces proteasomal degradation of sphingosine kinase 1 in mammalian cells. J Biol Chem. 2010; 285:38841-52

104. Van Brocklyn JR, Jackson CA, Pearl DK, Kotur MS, Snyder PJ, Prior TW. Sphingosine kinase-1 expression correlates with poor survival of patients with glioblastoma multiforme: roles of sphingosine kinase isoforms in growth of glioblastoma cell lines. J Neuropathol Exp Neurol. 2005;64:695-705.

105. Weigert A, Schiffmann S, Sekar D, Ley S, Menrad H, Werno C, Grosch S, Geisslinger G, Brune B. Sphingosine kinase 2 deficient tumor xenografts show impaired growth and fail to polarize macrophages towards an antiinflammatory phenotype. Int J Cancer. 2009;125:2114-21.

106. Antoon JW, White MD, Slaughter EM, Driver JL, Khalili HS, Elliott S, Smith CD, Burow ME, Beckman BS. Targeting NFkB mediated breast cancer chemoresistance through selective inhibition of sphingosine kinase-2. Cancer Biol Ther. 2011;11:678-89.

107. White MD, Chan L, Antoon JW, Beckman BS. Targeting ovarian cancer and chemoresistance through selective inhibition of sphingosine kinase-2 with ABC294640. Anticancer Res. 2013;33:3573-9.

108. Graler MH. Targeting sphingosine 1-phosphate (S1P) levels and S1P receptor functions for therapeutic immune interventions. Cell Physiol Biochem. 2010;26:79-86.

109. Brinkmann V, Billich A, Baumruker T, Heining P, Schmouder R, Francis G, Aradhye S, Burtin P. Fingolimod (FTY720): discovery and development of an oral drug to treat multiple sclerosis. Nature reviews. Drug discovery. 2010;9: 883-97.

110. Mullershausen F, Zecri F, Cetin C, Billich A, Guerini D, Seuwen K. Persistent signaling induced by FTY720-phosphate is mediated by internalized S1P1 receptors. Nat Chem Biol. 2009:5:428-34.

111. Mehling M, Brinkmann V, Antel J, Bar-Or A, Goebels N, Vedrine C, Kristofic C, Kuhle J, Lindberg RL, Kappos L. FTY720 therapy exerts differential effects on T cell subsets in multiple sclerosis. Neurology. 2008;71:1261-7. 